\title{
South American Aerosol Tracking - LALINET
}

\author{
Eduardo Landulfo ${ }^{1, *}$, Fabio Lopes ${ }^{1}$, Pablo Ristori ${ }^{2}$, Eduardo Quel $^{2}$, Lidia Otero ${ }^{2}$, Ricardo \\ Forno $^{3}$, Maria Fernanda Sanchez ${ }^{3}$, Henrique Barbosa ${ }^{4}$, Diego Gouveia ${ }^{4}$, Amanda Vieira \\ Santos $^{4}$, Alvaro Bastidas ${ }^{5}$ and Daniel Nisperuza ${ }^{5}$ \\ ${ }^{1}$ Instituto de Pesquisas Energéticas e Nucleares, Centro de Lasers e Aplicações, Av. Prof. Lineu \\ Prestes, 2242, São Paulo,05508000,Brazil, *elandulf@ipen.br \\ ${ }^{2}$ CITEDEF, CEILAP, San Juan Bautista de la Salle 4397, Buenos Aires, B1603ALO, Argentina \\ ${ }^{3}$ Laboratorio de Física de la Atmosfera, Universidad Mayor de San Andrés, La Paz, Bolivia \\ ${ }^{4}$ Dep. de Fisica Aplicada, U. de São Paulo, Rua do Matão, 1371, 05508-090, São Paulo, Brazil \\ ${ }^{5}$ Grupo de Investigación Láseres y Espectroscopia, Universidad Nacional de Colombia, \\ Medellín, Colombia
}

\begin{abstract}
LALINET lidar stations were used to track down aerosols generated over Amazon region and transported over the continent. These data were merged with collocated Aeronet stations in order to help in their identification together with HYSPLIT simulations. The results show potential indication of how aerosol can age in their long transport over regions South and Westward from the source areas by change of their optical properties.
\end{abstract}

\section{INTRODUCTION}

The transport of aerosols in South America has as one of its main sources those generated in the Amazon and adjacent regions[3]. The circulation pattern is well known and can make this particles reach most countries in the continent.During the transport which may last several days, 4-8 days, the aerosols which do not mix or are not removed may change their optical properties and affect the air quality and mix with those aerosols present in the areas they are detected. A consistent tracking of these changes might be performed by sattelites such as CALIOP and/or MODIS or by an array of instruments $[4,6,1]$ in order to increase modelling reliability .Aerosols from Amazon may change locally by water uptake or condensation of organics as suggested by Johnson $e$ t al.[2] or during transport into remote areas when more complex processes take place such as coagulation and gas-to-particle conversion and aerosolcloud-interaction[5] which should be taken into account as a valued source for potential aerosol aging studies.

\section{METHODOLOGY}

For this study 5 LALINET stations were used namely: Manaus(BR), Medellin(CO), La Paz(BO), Buenos Aires(AR) and São Paulo(BR), the station information are given in table below. Their location span over the entire continent and could be affected by transport from biomass burning activities. Collocated with these stations are AERONET sunphotmeter stations which synergizes with the local lidar instruments. Besides HYSPLIT simulations were made on specific days for arriving air masses at $3000 \mathrm{~km}$, a.g.l., to help in identifying potential aerosols sources present on the lidar routine measurements carried on by the network. This first approach is to comprehend the overall pattern circulation present on the station sites and also to better undestand possible $a$ ging effects, at first quantitatively. 
Table 1: LALINET Lidar Stations

\begin{tabular}{|c|c|c|c|}
\hline ST. & ID & $\begin{array}{c}\text { LAT(S) } \\
\text { LON(W) }\end{array}$ & $\begin{array}{c}\text { Channels } \\
(\mathbf{n m})\end{array}$ \\
\hline $\begin{array}{c}\text { Buenos } \\
\text { Aires }\end{array}$ & AEP & $\begin{array}{c}34^{\circ} 33^{\prime} \\
58^{\circ} 25^{\prime}\end{array}$ & $\begin{array}{c}1064,532^{p} \\
\& 355^{p}\end{array}$ \\
\hline $\begin{array}{c}\text { S. } \\
\text { Paulo }\end{array}$ & SPU & $\begin{array}{c}23^{\circ} 13^{\prime} \\
46^{\circ} 88^{\prime}\end{array}$ & $\begin{array}{c}1064,607, \\
532,408, \\
387 \& 355\end{array}$ \\
\hline $\begin{array}{c}\text { Man- } \\
\text { aus }\end{array}$ & MAO & $\begin{array}{c}02^{\circ} 60^{\prime} \\
60^{\circ} 21^{\prime}\end{array}$ & $\begin{array}{c}408, \\
387,355\end{array}$ \\
\hline $\begin{array}{c}\text { Medellin } \\
\text { La Paz }\end{array}$ & MED & $\begin{array}{c}-06^{\circ} 16^{\prime} \\
75^{\circ} 35^{\prime}\end{array}$ & $\begin{array}{c}532 \& 355 \\
16^{\circ} 32^{\prime}\end{array}$ \\
$72^{\circ} 04^{\prime}$ & $\begin{array}{c}1064,532^{p} \\
\& 355^{p}\end{array}$ \\
\hline
\end{tabular}

\section{RESULTS}

\subsection{Sunphotometric Results}

The stations have collocated AERONET stations which provide informations on the aerosol optical properties such as Aerosol Optical Depth (AOD) and Angström Exponent (AE). In figures 1 and 2 one can see the AOD statistics in 2016 and AOT $\times$ AE for the same period in the 5 LALINET stations. The MED station is the one presenting the largest variability and certainly influence by aerosos from local and remote sources. The plots show also a large variability in MED station, while MAO,LPZ, SPU and BUE are those which present less change with a mean value of $0.19 \pm$ $0.11,0.10 \pm 0.09,0.19 \pm 0.12$ and $0.11 \pm$ 0.12 , respectively. On other hand as forementioned, MED has an AOD mean value of $0.43 \pm$ 0.42 . When looking at size range one checks the Angström Exponent values and variability: $A E_{S P}=1.50 \pm 0.21, A E_{M A O}=1.26 \pm 0.34$, $A E_{B U E}=1.25 \pm 0.47, A E_{L P Z}=0.82 \pm 0.37$, $A E_{M E D}=1.19 \pm 0.47$.

Among many cases when high values of AOD

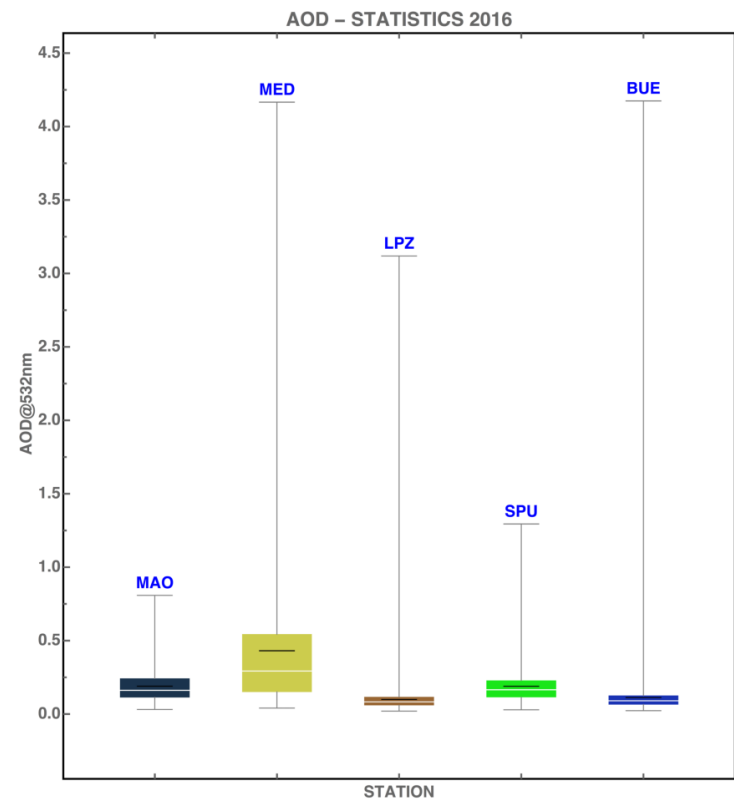

Figure 1: AOD Statistics for 2016among LALINET stations.

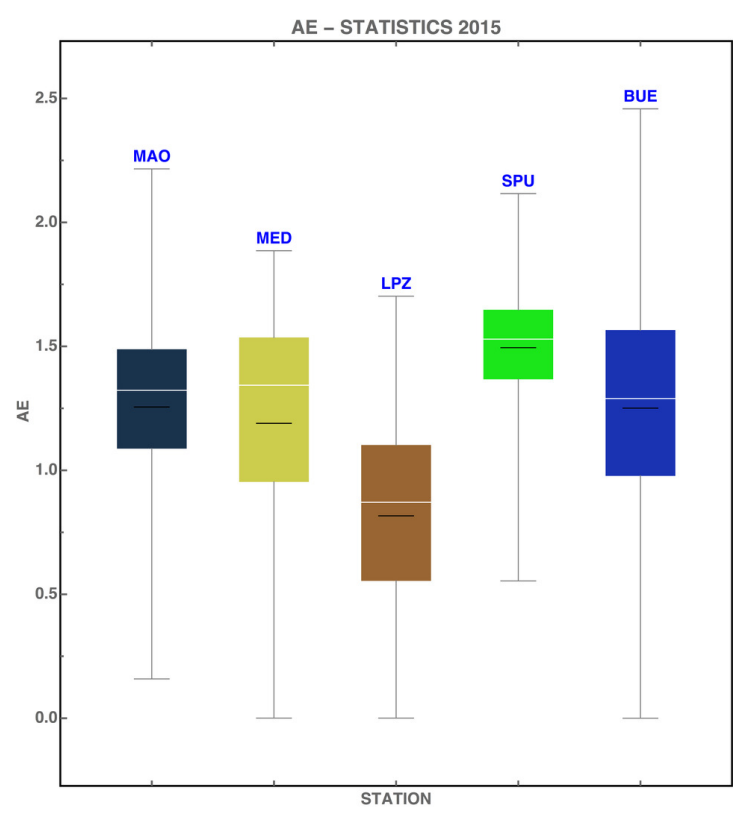

Figure 2: AE Statistics for 2016 among LALINET stations

were present in all the stations we have selected some specific days, namely August 25, September 10, September 19, November 28, in 2016, 
when air mass transport into the stations are shown by HYSPLIT simulations. The chosen arrival altitude was $3000 \mathrm{~m}$ to minimize is this first study Planetary Boundary Layer (PBL) and uncomplete overlap effects. It is important to note that the different circulation patterns playing a role in the continent show a potential variety of aerosols from Atlantic/African origin to in-continental sources, dust, marine/clear and biomass burning. Also it is noteworthy that some pair (threewise as well) of station could be used to track the aerosol properties and possible aging and changes in their optical properties. For example : MAO-LPZ-MED or BUESPU groups. Of course this approach could be extended to other LALINET stations thus enhancing the regional coverage. Also the aerosol typing according to the source region allows to identify saharan dust and biomass burning events in the case o MAO, LPZ and MED. When one looks at the Range Corrected Sig-
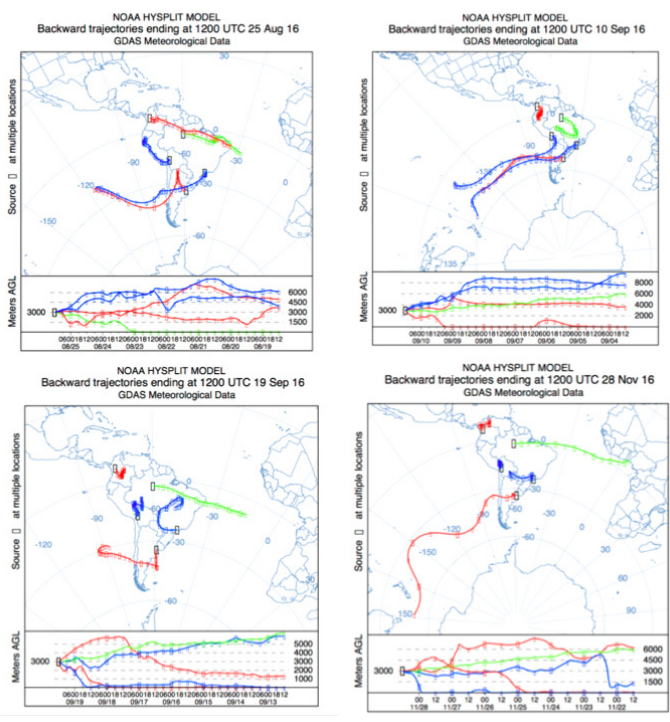

Figure 3: HYSPLIT backtrajectory simulation over LALINET stations arriving on September 19, 2016.

nal data from the stations it is possible to verify the layering structure over the lidar sites being supported and/or validating the HYSPLIT simulations in the instances shown. The RCS plots corrspond to the Monday/Thursday routine measurements taken by the network. Beggining by the AER station in Buenos Aires on November, 28, a mixing of Pacific marine and continental (dust) is present in the Argentinian city up to $6 \mathrm{~km}$ with a clear enhancement of signal above $2 \mathrm{~km}$. The bolivian site, the $c$ leanest site, show the presence of aerosols up to 3 - 4 $\mathrm{km}$ a.g.l. but this station is in the Andean mountain range and close to La Paz. Both Manaus and São Paulo stations are represented on $\mathrm{Au}-$ gust, 25, exemplifying the two different circulation patterns present in the continent, while Manaus is influenced by a wersterly air mass bringing diffent types of aerosols, São Paulo, the largest urban site, shows a heavy load of aerosols with a well defined PBL and a transported air mass originating in the Pampas region in the southern part of the continent. Finally the Medellin station on September, 19, shows that even though air masses show advection from local areas the presence of aerosols aloft the PBL plus the presence of low-middle clouds poses a challenge in studiyng aerosols in the areas with largest values of AOD's.

\section{CONCLUSIONS}

This first study on identifying the local and transported aerosol layers in 5 different LALINET stations presented here show an important step towards the aerosol optical properties based on their potential sources, while this procedure is not new, it is for South America. By the extension of the timeseries from only one year in this study, 2016, to a longer period will show reveal important patterns in the aerosol study. Also the inclusion of other netwrok station not presented here for the sake of brevity will improve the results. 


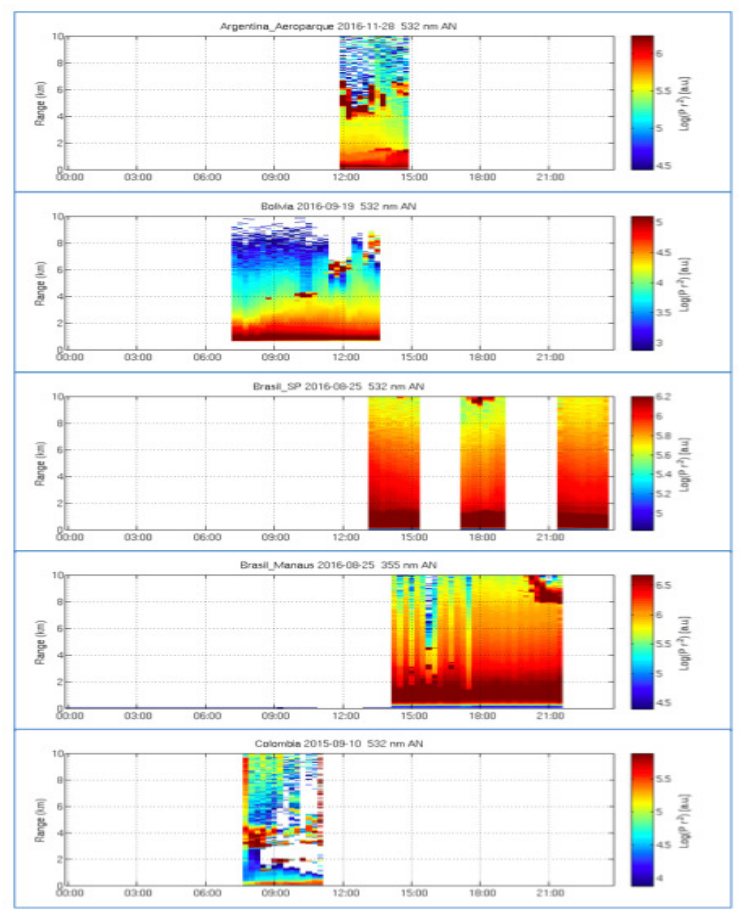

Figure 4: Range Corrected Signal for the five LALINET stations. The dates correspond to the Monday/Thursday measurement protocol.

\section{ACKNOWLEDGEMENTS}

This work was also partially funded by the University of Granada through the contract Plan Propio. Programa 9. Convocatoria 2013, additional support was given by Universidad Nacional Sede Medellín, NASA-AERONET. We are also indebted with NIES science partner, namely Dr. Yoshitaka Jin and Nobuo Sugimoto on the data transfer and storage in their facilties.

\section{References}

[1] Y. Hara, K. Yumimoto, I. Uno, A. Shimizu, N. Sugimoto, Z. Liu, and D. M. Winker. Asian dust outflow in the pbl and free atmosphere retrieved by NASA CALIPSO and an assimilated dust transport model. Atmospheric Chemistry and Physics, 9(4):12271239, 2009.
[2] B. T. Johnson, J. M. Haywood, J. M. Langridge, E. Darbyshire, W. T. Morgan, K. Szpek, J. K. Brooke, F. Marenco, H. Coe, P. Artaxo, K. M. Longo, J. P. Mulcahy, G. W. Mann, M. Dalvi, and N. Bellouin. Evaluation of biomass burning aerosols in the HadGEM3 climate model with observations from the SAMBBA field campaign. Atmospheric Chemistry and Physics, 16(22):14657-14685, 2016.

[3] E. Landulfo, S. R. Freitas, K. M. Longo, S. T. Uehara, and P. Sawamura. A comparison study of regional atmospheric simulations with an elastic backscattering lidar and sunphotometry in an urban area. Atmospheric Chemistry and Physics, 9(18):6767-6774, 2009.

[4] Jianfei Peng, Min Hu, Zhaoheng Gong, Xudong Tian, Ming Wang, Jing Zheng, Qingfeng Guo, Wei Cao, Wei Lv, Weiwei $\mathrm{Hu}$, Zhijun $\mathrm{Wu}$, and Song Guo. Evolution of secondary inorganic and organic aerosols during transport: A case study at a regional receptor site. Environmental Pollution, 218:794 - 803, 2016.

[5] Jeffrey S. Reid, Thomas F. Eck, Sundar A. Christopher, Peter V. Hobbs, and Brent Holben. Use of the angstrom exponent to estimate the variability of optical and physical properties of aging smoke particles in Brazil. Journal of Geophysical Research: Atmospheres, 104(D22):2747327489, 1999.

[6] F. Waquet, F. Peers, P. Goloub, F. Ducos, F. Thieuleux, Y. Derimian, J. Riedi, M. Chami, and D. Tanré. Retrieval of the Eyjafjallajökull volcanic aerosol optical and microphysical properties from POLDER/PARASOL measurements. Atmospheric Chemistry and Physics, 14(4):1755-1768, 2014. 